\title{
Stable isotopes as measure of niche breadth of nesting green turtles (Chelonia mydas) on Rocas Atoll, Brazil
}

The study analysed the niche breadth of nesting green turtles, Chelonia mydas, on Rocas Atoll, Brazil, through stable isotopes (d15N and d13C), comparing samplings of egg yolk and carapace collected from two nesting groups (2017 and 2019). The mean d15N values in egg yolk and carapace were 7.1\%o (2017) and $6.8 \%$ (2019), and 7.8\%o (2017) and 7.3\%o (2019), respectively. For d13C, the mean values were $-17.4 \%$ (2017) and $-17.5 \%$ o (2019) in egg yolk, and -18.4\%o (2017) and $-17.9 \%$ (2019) in carapace. The results suggest herbivory in coastal-benthic environments as the main feeding pattern in this nesting population. The niche breadth was similar between 2017 and 2019 in both tissues. In general, the trophic diversity (NR, CR, CD and SEA) was comparable between years as well as the trophic redundancy (MNND and SDNND), which was overall high. The niche metrics pointed to a homogeneous feeding pattern in the two nesting groups (2017 and 2019). This study adds a piece to solve the puzzle of adult green turtle trophic ecology.

Keywords: Stable isotopes; Marine turtle; Trophic ecology; South Atlantic Ocean.

\section{Isótopos estáveis como medida de amplitude de nicho de tartarugas verdes (Chelonia mydas) nidificantes no Atol das Rocas, Brasil}

O estudo analisou a amplitude do nicho de tartarugas verdes, Chelonia mydas, no Atol das Rocas, Brasil, por meio de isótopos estáveis (d15N e d13C), comparando amostragens de gema de ovo e carapaça coletadas de dois grupos de nidificação (2017 e 2019). Os valores médios de d15N na gema do ovo e na carapaça foram $7,1 \%$ (2017) e 6,8\%o (2019), e 7,8\%o (2017) e 7,3\%o (2019), respectivamente. Para d13C, os valores médios foram -17,4\% (2017) e -17,5\% (2019) na gema de ovo, e -18,4\%o (2017) e -17,9\% (2019) na carapaça. Os resultados sugerem que a herbivoria em ambientes costeiros-bentônicos é o principal padrão alimentar nesta população. A amplitude do nicho foi semelhante entre 2017 e 2019 em ambos os tecidos. Em geral, a diversidade trófica (NR, CR, CD e SEA) foi comparável entre os anos, assim como a redundância trófica (MNND e SDNND), que em geral foi elevada. As métricas de nicho apontaram para um padrão de alimentação homogêneo nos dois grupos de nidificação (2017 e 2019). Este estudo adiciona uma peça para resolver o quebra-cabeça da ecologia trófica da tartaruga verde adulta.

Palavras-chave: Isótopos estáveis; Tartaruga marinha; Ecologia trófica; Oceano Atlântico Sul.

Topic: Conservação da Biodiversidade

Reviewed anonymously in the process of blind peer.
Received: 04/03/2021

Approved: 23/03/2021
Karoline Fernanda Ferreira Agostinho

Universidade Estadual do Norte Fluminense Darcy Ribeiro, Brasil http://lattes.cnpq.br/4708753129556967 http://orcid.org/0000-0001-9938-9471

karolineferreira@pq.uenf.br

Leandro Rabello Monteiro (iD

Universidade Estadual do Norte Fluminense Darcy Ribeiro, Brasil http://lattes.cnpq.br/4987216474124557

http://orcid.org/0000-0002-0725-3647

Irmont@uenf.br

Carlos Eduardo Veiga de Carvalho (iD)

Universidade Estadual do Norte Fluminense Darcy Ribeiro, Brasil http://lattes.cnpq.br/5814379117254232

http://orcid.org/0000-0002-7704-9588

carvalho@uenf.br
Ana Paula Madeira Di Beneditto (iD)

Universidade Estadual do Norte Fluminense Darcy Ribeiro, Brasil http://lattes.cnpq.br/8402221071942314 http://orcid.org/0000-0002-4248-9380

anapaula@uenf.br
Referencing this:

AGOSTINHO, K. F. F.; MONTEIRO, L. R.; CARVALHO, C. E. V.; BENEDITTO, A. P. M.. Stable isotopes as measure of niche breadth of nesting green turtles (Chelonia mydas) on Rocas Atoll, Brazil. Revista Ibero Americana de Ciências Ambientais, v.12, n.3, p.82-89, 2021. DOI: http://doi.org/10.6008/CBPC2179-6858.2021.003.0008 


\section{INTRODUCTION}

The green turtle Chelonia mydas Linnaeus, 1758 occurs in all ocean basins in tropical and sub-tropical regions. The conservation efforts in Brazil and worldwide reduced intentional captures and eggs harvesting, but the species is still vulnerable to fisheries and marine pollution (BRODERICK et al., 2019). Like other marine turtles, this species does extensive migrations for thousands of kilometers between foraging and breeding sites, with high site fidelity for both sites (BELLINI et al., 2013; BAUDOUIN et al., 2015; SHIMADA et al., 2020).

The Rocas Atoll $\left(03^{\circ} 51^{\prime} \mathrm{S}\right.$; $33^{\circ} 49^{\prime} \mathrm{W}$ ) is a Brazilian marine reserve situated $266 \mathrm{~km}$ off the coastline, and it is the second largest nesting site for the green turtle in Brazil (BELLINI et al., 2013) (Figure 1). Genetic evidences highlighted the green turtles on Rocas Atoll as key individuals for maintaining the diversity of the species in the South Atlantic Ocean (BJORNDAL et al., 2006). Bellini et al. (2013) monitored the nesting females in Rocas Atoll for 19 consecutive years: the peak of nesting season occurs from February to April, the average number of females and nests per season were 73 and 335, respectively (5.2 nests per individual), internesting period ranged from 8-17 days and remigration period was 3.5 years. The authors speculate that these nesting females could come from several foraging sites, although the locations of these sites are still unknown.

Stable isotopes are chemical proxies whose utilization allow inferences on animals' trophic ecology. The isotopic composition of the animal tissues derives from its trophic pathway, corresponding to the isotopic composition of their food resources and trophic habitat after the food assimilation and fractionation processes in the tissues (LAYMAN et al., 2007; NEWSOME et al., 2007; FRY, 2008). Each body tissue has a specific turnover time, i.e. time within which stable isotopes in tissue is replaced by stable isotopes derived from food (AUERSWALD et al., 2010). Keratinous tissue, like carapace scutes, is metabolically inert, representing the dietary information from years ago (HOBSON, 1999). The isotopic profile of egg yolk in marine turtles represents the food assimilation in a narrower temporal window when compared to carapace scutes. The vitellogenesis process happens 4 to 6 months before the female's migration to the breeding site, while she is still at the feeding site (ROSTAL et al., 1998).

Individuals from the same population do not necessarily have consistent foraging strategies over time, changing the consumed food resources (BEARHOP et al., 2004; RIO et al., 2009). Niche differentiation is the process by which species evolve different forms of food resource utilization (MACARTHUR, 1984). Bearhop et al. (2004) and Newsome et al. (2007) expanded the niche theory using stable isotopes as a measure of niche breadth, while Layman et al. (2007) introduced metrics from ecomorphological approaches to summarize the quantitative niche information from stable isotopes. Jackson et al. (2011) developed a Bayesian framework for comparing these metrics, allowing inferences regarding the isotopic niche of consumers. Therefore, stable isotopes are reliable tools to provide quantitative information about the consumer isotopic niche, which is associated with its ecological niche.

Based on the above assumptions, this study applied stable isotopes to analysed the niche breadth of nesting green turtles on Rocas Atoll (Figure 1), comparing samplings from two nesting groups (2017 and 
2019). The egg yolk represents the food assimilation from a few months before oviposition, whereas carapace fragments represent the food assimilation from years ago, i.e. in a more comprehensive temporal dimension. The isotopic niche approach will provide clues on how nesting individuals use the resources over time.

\section{METHODOLOGY}

\section{Sampling and stable isotopes $\left(\delta^{13} \mathrm{C}\right.$ and $\left.\delta^{15} \mathrm{~N}\right)$ analysis}

The nesting green turtles were sampled in Rocas Atoll in 2017 and 2019 nesting seasons (January to March), herein refer as years (Figure 1). Each year represents a given nesting group, since the individuals were not resampled between years nor within the same year. The sample size in each year is in table 1 . In 2017, the samplings of egg and carapace did not necessarily belong to the same female, but in 2019 both tissues were sampled from the same individual. Fresh eggs (2019) and carapace (2017 and 2019) samplings began as soon as the female initiated egg laying. During sampling, each female was measured for curved carapace length, from the nuchal notch to the tip of the longest posterior marginal scute $(\mathrm{cm})$, and microchipped for individual identification. In 2017, unhatched intact eggs were sampled directly from the nest. Since each nest had an identification tag, individual turtles were sampled only once.

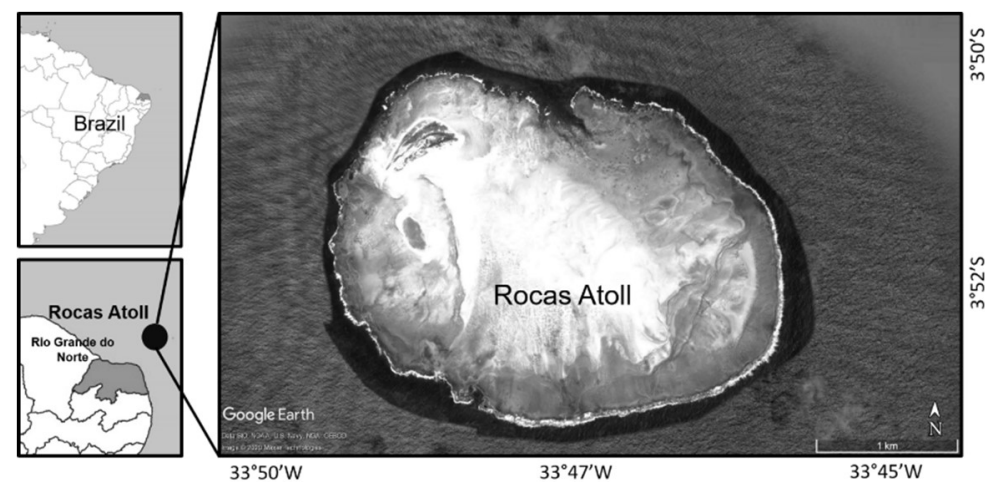

Figure 1: The location of Rocas Atoll, the nesting site for the green turtle in Brazil, southwestern Atlantic Ocean.

After sampling, the eggs were rinsed in filtered water, opened, and egg yolk separated from other fractions (albumen and shell). Then, a bulk sample with two egg yolks from the same nest/female was stored in a clean transparent plastic bag. One gram of wet weight of egg yolk (bulk sample) was freeze-dried and ground into a homogeneous powder. The egg yolk has $>50 \%$ of lipid content in freeze-dried samples, and the samples were treated using a 2:1 solvent mixture of chloroform and methanol prior to lipid extraction (BLIGH et al., 1959; CARPENTIER et al., 2015). This procedure minimizes bias in $\delta^{13} \mathrm{C}$ values interpretation (POST et al., 2007).

A carapace fragment $\left(5 \mathrm{~cm}^{2}\right)$ was sampled from the margin of the anterior scute, close to the nuchal notch. The sample was immersed in pure acetone to dissolve any incrustation. Then, it was rinsed in filtered water, air dried, grounded into a homogeneous powder and stored in a clean transparent plastic vial. This fragment does not represent the oldest part of the carapace (LOPÉZ-CASTRO et al., 2014), but since all samples were collected in the same way, bias in the data interpretation is not expected. 
The stable isotope ratios $\left(\delta^{13} \mathrm{C}\right.$ and $\delta^{15} \mathrm{~N}$ ) were determined in $0.3-0.4 \mathrm{mg}$ of dry weight of each sample (egg yolk and carapace) in an organic elemental analyzer (Flash 2000, Thermo Scientific) coupled with a mass spectrometer (Delta V Advantage Isotope Ratio Mass Spectrometer, Thermo Scientific) through the ConFloVI interface (Model BR30140, Thermo Scientific). The stable isotope analyses were performed in the Laboratório de Ciências Ambientais at Universidade Estadual do Norte Fluminense Darcy Ribeiro. Reference values were Pee Dee Belemnite (PDB) and atmospheric nitrogen. The samples were analyzed using analytical blanks and urea analytical standards (IVA Analysentechnik-330802174). The analytical control was done for every 10 samples using a certified isotopic standard (Elemental Microanalysis Protein Standard OAS), and the reproducibility was based on triplicates for every 10 samples $\left( \pm 0.2 \%, \delta{ }^{13} \mathrm{C} ; \pm 0.3 \%\right.$, $\left.\delta^{15} \mathrm{~N}\right)$. The results are presented as parts per thousand (\%o).

\section{Niche breath analysis}

Quantitative metrics based on the position of each green turtle in the space $\delta^{13} \mathrm{C}-\delta^{15} \mathrm{~N}$ estimated the isotopic niche breadth for individuals sampling in each year, according to Layman et al. (2007) and Jackson et al. (2011). Since egg yolk and carapace represent different temporal windows in food assimilation (last months vs. years), comparisons were done only within the same tissue. The quantitative metrics were calculated by the functions for Stable Isotope Bayesian Ellipses in R (SIBER - JACKSON et al., 2011; R CORE TEAM, 2020). The Bayesian assessment for the comparison of isotopic niche metrics proposed by Jackson et al. (2011) is appropriate for small sample sizes (at least 10 samples), as in the present study (Table 1 ).

The first four metrics described below represent the trophic diversity in the space $\delta^{13} \mathrm{C}-\delta^{15} \mathrm{~N}$, while the other two metrics represent the trophic redundancy (LAYMAN et al., 2007). The $\delta^{15} \mathrm{~N}$ range (NR metric), is the distance between maximum and minimum $\delta^{15} \mathrm{~N}$ values, which means the trophic breadth. The $\delta^{13} \mathrm{C}$ range $(C R)$ is the distance between maximum and minimum $\delta^{13} \mathrm{C}$ values, indicating variability in basal resources. The standard ellipse area (SEA) is the trophic niche breadth, centred on the group centroid and scaled to encompass a $40 \%$ chance $(p=0.40)$ of including a subsequently sampled datum. The mean distance to centroid $(C D)$ is the average Euclidean distance of each individual to the group centroid (mean $\delta^{15} \mathrm{~N}$ and $\delta^{13} \mathrm{C}$ values). The mean nearest neighbour distance (MNND) is the average Euclidean distance to the individual's nearest neighbour in the space $\delta^{13} \mathrm{C}-\delta^{15} \mathrm{~N}$, where a set of many individuals with similar trophic ecologies would have a smaller MNND than a set in which individuals have a more diverse diet. The last metric is SDNND (standard deviation of nearest neighbour distance), which is a measure of evenness in the scatterplot, with low values indicating a more even distribution of individuals in the trophic niche space.

The differences between each year regarding mean $\delta^{15} \mathrm{~N}$ and $\delta^{13} \mathrm{C}$ values in egg yolk and carapace were assessed via t-tests. The SEAs were compared probabilistically with the posterior Bayesian distributions, calculating the proportion of ellipses for group 1 that was larger than (or equal to) ellipses for group 2 in the simulated draws (JACKSON et al., 2011). The percent of overlapping SEA between years was the measure of isotopic niche overlap. T-tests were used to assess differences between years considering CD and MNND metrics because they are means. Because SDNND is a standard deviation, it was compared (after squaring) 
by an F-ratio test.

\section{RESULTS}

Curved carapace length of the nesting green turtles showed little variation within the same year, as demonstrated by the standard deviation, and between years, as verified by the mean values (Table 1). No statistical support for mean differences between years were recorded for the isotopic values in both tissues (Table 1).

The SEAs that represent 2017 and 2019 samplings were similar in size and position in the $\delta^{13} \mathrm{C}-\delta^{15} \mathrm{~N}$ scatterplot for egg yolk samples, while for carapace samples the SEA of 2019 was greater than 2017, but with similar position in the $\delta^{13} \mathrm{C}-\delta^{15} \mathrm{~N}$ scatterplot (Figure 2 and Table 1). A probabilistic comparison between the ellipse areas based on the posterior distribution of simulated ellipses indicated that $48.6 \%$ and $91.6 \%$ of the SEAs of 2019 are larger than 2017 in egg yolk and carapace samples, respectively.

For egg yolk samples, the trophic diversity metrics (NR, CR, CD and SEA) were similar between years, and $C D$ did not present a clear difference between them $(t=0.144, \mathrm{df}=30.7, p=0.886)$ (Table 2). For the trophic redundancy metrics, representing how closely positioned individuals are to each other within their respective niches, MNND values were low and did not show difference between years $(t=-0.54, \mathrm{df}=32.6, p=$ 0.593), while SDNND values were low, but different between years ( $F=3.94, p=0.0045)$ (Table 2).

Table 1: Sample size $(\mathrm{n})$, curved carapace length $(\mathrm{CCL}$ in $\mathrm{cm}$ ) and stable isotopes values (\%o) of nesting green turtles on Rocas Atoll. Values are mean \pm standard deviation and $p$-values represent the t-tests results that compared the stable isotope values between years.

\begin{tabular}{|l|l|l|l|l|l|}
\hline & $\mathbf{n}$ & $\mathrm{CCL}$ & $\boldsymbol{\delta}^{13} \mathrm{C}$ & $\begin{array}{l}\boldsymbol{p} \text {-values } \\
\mathbf{2 0 1 7} \times \mathbf{2 0 1 9}\end{array}$ & $\begin{array}{l}\boldsymbol{\delta}^{15} \mathbf{N} \\
\mathbf{2 0 1 7} \times \mathbf{2 0 1 9}\end{array}$ \\
\hline Egg yolk & & & & & \\
\hline $\mathbf{2 0 1 7}$ & 16 & - & $-17.4 \pm 2.2$ & & $7.1 \pm 1.2$ \\
\hline $\mathbf{2 0 1 9}$ & 22 & $112.8 \pm 4.9$ & $-17.5 \pm 2.1$ & 0.828 & $6.8 \pm 1.3$ \\
\hline Carapace & & & & & \\
\hline $\mathbf{2 0 1 7}$ & 39 & $110.7 \pm 5.1$ & $-18.4 \pm 2.2$ & \multirow{2}{*}{0.332} & $7.8 \pm 1.5$ \\
\hline $\mathbf{2 0 1 9}$ & 22 & $112.8 \pm 4.9$ & $-17.9 \pm 2.3$ & & $7.3 \pm 1.5$ \\
\hline
\end{tabular}
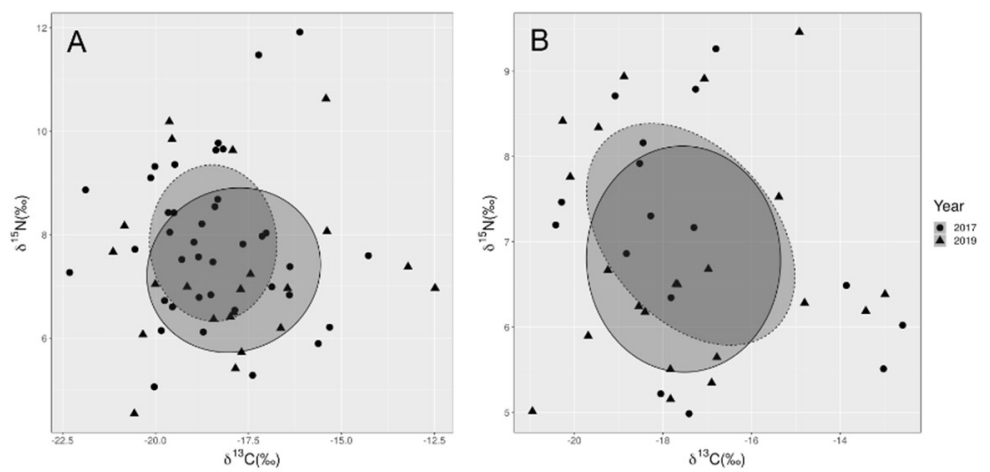

Figure 2: $\delta^{13} \mathrm{C}-\delta^{15} \mathrm{~N}$ scatterplot of the nesting green turtles on Rocas Atoll (A: egg yolk and B: carapace). Lines depict the standard ellipse (the $40 \%$ confidence interval) for the isotopic niches. The dotted line is the ellipse for 2017 and the solid line is the ellipse for 2019.

For carapace samples, the trophic diversity metrics were similar between years, except for SEA as mentioned above, and the trophic redundancy metrics had similar behavior (Table 2). Neither CD nor MNND nor SDNND presented significant differences between years $(C D: t=-1.27, \mathrm{df}=36.9, p=0.209$; $\mathrm{MNND}$ : $\mathrm{t}=-$ 
$1.63, \mathrm{df}=35.6, p=0.112 ; \mathrm{SDNND}: \mathrm{F}=1.64, p=0.0906)$. Considering the percentages of SEA overlap between years, the values for egg yolk were higher than $80 \%$ in both years, and for carapace samples, they ranged from $57 \%$ to $83 \%$ (Figure 2 ).

Table 2: Quantitative niche metrics of nesting green turtles on Rocas Atoll for egg yolk and carapace. NR= $\delta^{15} \mathrm{~N}$ range, $\mathrm{CR}=\delta^{13} \mathrm{C}, \mathrm{SEA}=$ standard ellipse area, $\mathrm{CD}=$ distance to centroid, $\mathrm{MNND}=$ mean nearest neighbour distance, $\mathrm{SDNND}=$ standard deviation of nearest neighbour distances, $L Q=$ lower quartile, and $U Q=$ upper quartile.

\begin{tabular}{|l|l|l|l|l|l|l|l|l|}
\hline & NR & CR & CD & MNND & SDNND & \multicolumn{2}{l|}{ SEA (\%o $\left.\mathbf{~}^{2}\right)$} & \\
\cline { 6 - 10 } & & & & & & LQ & Median & UQ \\
\hline 2017 & 4.3 & 7.8 & 2.2 & 0.6 & 0.3 & 7.9 & 9.1 & 10.6 \\
\hline 2019 & 4.4 & 7.9 & 2.2 & 0.7 & 0.5 & 7.6 & 8.9 & 10.6 \\
\hline Carapace & & & & & & & & \\
\hline 2017 & 6.8 & 8.0 & 1.9 & 0.5 & 0.5 & 7.2 & 8.0 & 9.0 \\
\hline 2019 & 6.1 & 8.6 & 2.4 & 0.8 & 0.6 & 10.0 & 11.5 & 13.4 \\
\hline
\end{tabular}

\section{DISCUSSION}

The isotopic profile of adult female green turtles on Rocas Atoll suggests that herbivory in coastalbenthic environments is the main feeding pattern for both nesting groups (2017 and 2019). Despite Thomson et al. (2018) presenting caveats in comparisons of isotopic profile at different spatial scales, even within the same species and gender-age class, comparisons between our results and current literature support this statement. The mean $\delta^{15} \mathrm{~N}$ values of our nesting green turtles (7.3\%o and 7.8\%o) are within the isotopic range in carapace of nesting green turtles from the Caribbean region (2.5\% to $9.9 \%$ ), which are known as primary herbivores (ZANDEN et al., 2013a; 2013b). Conversely, Hatase et al. (2006) determined the isotopic composition in egg yolks of omnivore green turtles in Pacific Ocean, whose mean $\delta^{15} \mathrm{~N}$ value was $11.4 \%$, which is $4 \%$ o heavier than our egg yolk samples $(6.8 \%$ ond $7.1 \%$ o). This difference is large enough to distinguish a trophic level, separating herbivore from omnivore-carnivore consumers (FRY, 2008).

Heavier $\delta^{13} \mathrm{C}$ values (less negative) are usually associated with coastal-benthic environments (FRY, 2008). The mean $\delta^{13} \mathrm{C}$ values in the egg yolk on Rocas Atoll (-17.4\%o and $-17.5 \%$ ), for instance, is $2 \%$ o heavier than egg yolk of the leatherback turtle (Dermochelys coriacea). The leatherback turtle is a pelagic-oceanic consumer whose mean $\delta^{13} \mathrm{C}$ values are -19.2\%o (Pacific Ocean) and -19.9\%o (Atlantic Ocean) (WALLACE et al., 2006). The difference from $2 \%$ in $\delta^{13} \mathrm{C}$ values can distinguish coastal-benthic vs. pelagic-oceanic consumers (FRY, 2008).

The carapace $\delta^{15} \mathrm{~N}$ in nesting green turtles on Rocas Atoll is typical from an herbivore habit, but the NR metric, a measure of trophic breadth that includes the range of $\delta^{15} \mathrm{~N}$ values among individuals, indirectly suggests contribution of animal matter to the diet over time. The NR from egg yolk, representing the diet from few months before oviposition, while females are in the foraging sites, is 1.5 times lower than NR from carapace, which tracks the diet from years ago. A larger NR implies that a consumer might overlap more than one trophic level, suggesting omnivore (LAYMAN et al., 2007). Since tissues have different metabolic and turnover rates, they were independent samples in the niche breadth analysis; however, the isotopic load of egg yolk is contained in the isotopic load of the carapace. Therefore, direct comparison between NR values in egg yolk and carapace has biological meaning, mainly for 2019 samplings when both tissues came from 
the same individual.

The niche breadth of nesting green turtles on Rocas Atoll was similar between years, in both tissues (egg yolk and carapace). The trophic diversity (NR, CR, CD and SEA) was comparable between years as well as the trophic redundancy (MNND and SDNND), which was overall high (values $<1.0$ ), revealing individuals with similar trophic ecologies and even distribution in the trophic niche space (LAYMAN et al., 2007). The only noteworthy difference between years was the SEA of carapace samples, larger in 2019 than in 2017; however, the SEAs overlap (57\%-83\%) suggest that this difference does not represent marked differences in the trophic niches.

\section{CONCLUSIONS}

The isotopic niche approach provided clues on how individuals from different nesting groups that nested in the same site are using the food resources over time (few months ago and years ago). The niche breadth alone does not allow inferences on foraging sites location, but this approach adds a piece to solve the puzzle of adult green turtle trophic ecology, presenting for the first time the isotopic signatures of nesting females on Rocas Atoll. Regardless of the original foraging site, the niche metrics pointed to a homogeneous feeding pattern in the two nesting groups (2017 and 2019), i.e. metrics are similar in both years.

Since the green turtle has a complex foraging strategy, with variations in feeding preference and trophic habitats along its wide distribution and among and within life-stages, we recommend multiple-tissue analysis to track any temporal variation in foraging habitats through stable isotopes. The utilization of trophic metrics or trophic models instead of stable isotopes values alone is interesting because some trophic details, such as suggested by $\delta^{15} \mathrm{~N}$ range (NR metric) in this study, could be lost, limiting a comprehensive understanding of the species trophic ecology.

ACKNOWLEDGMENTS: We are indebted to Dr. Marcelo Gomes de Almeida for the stable isotopes analysis, to Jarian Dantas for helping during field activities and to Maurizélia de Brito Silva, coordinator of Biological Reserve of Rocas Atoll, for logistic support in the field campaigns. The Instituto Chico Mendes de Conservação da Biodiversidade (ICMBio), Fundação SOS Mata Atlântica and FUNBIO/Banco Mundial (GEFMAR project) support the field campaigns. This study was funded by Conselho Nacional de Desenvolvimento Científico e Tecnológico - CNPq (grant 301.259/2017-8), Fundação Carlos Chagas Filho de Amparo à Pesquisa do Estado do Rio de Janeiro - FAPERJ (grants E-26/202.770/2017, E-26/210.064/2018 and E-26/210.883/2016), and Coordenação de Aperfeiçoamento de Pessoal de Nível Superior - Brasil (CAPES) - Finance Code 001.

\section{REFERENCES}

AUERSWALD, K.; WITTMER, M. H. O. M.; ZAZZO, A.; SCHÄUFELE, R.; SCHNYDER, H.. Biases in the analysis of stable isotope discrimination in food webs. Journal of Applied Ecology, v.47, p.936-941, 2010. DOI: https://doi.org/10.1111/j.1365-2664.2009.01764.x

BAUDOUIN, M.; THOISY, B.; CHAMBAULT, P.; BERZINS, R.;
ENTRAYGUES, M.; KELLE, L.; TURNY, A.; LE MAHO, Y.; CHEVALLIER, D.. Identification of key marine areas for conservation based on satellite tracking of post-nesting migrating green turtles (Chelonia mydas). Biological Conservation, v.184, p.36-41, 2015. DOI: http://dx.doi.org/10.1016/j.biocon.2014.12.021 
BEARHOP, S.; ADAMS, C. E.; WALDRON, S.; FULLER, R. A.; MACLEOD, H.. Determining trophic niche width: A novel approach using stable isotope analysis. Journal of Animal Ecology, v.73, p.1007-1012, 2004. DOI: https://doi.org/10.1111/j.0021-8790.2004.00861.x

BELLINI, C.; SANTOS, A. J.; GROSSMAN, A.; MARCOVALDI, M. A.; BARATA, P. C.. Green turtle (Chelonia mydas) nesting on Atol das Rocas, north-eastern Brazil, 1990-2008. Journal of the Marine Biological Association of United Kingdom, v.93, p.1117-1132, 2013. DOI: https://doi.org/10.1017/S002531541200046X

BJORNDAL, K. A.; BOLTEN, A. B.; MOREIRA, L.; BELLINI, C.; MARCOVALDI, M. A.. Population structure and diversity of Brazilian green turtle rookeries based on mitochondrial DNA sequences. Chelonian Conservation Biology, v.5, p.262-268, 2006. DOI: https://doi.org/10.2744/10718443(2006)5[262:PSADOB]2.0.CO;2

BLIGH, E. G.; DYER, W. J.. A rapid method of total lipid extraction and purification.Canadian Journal of Biochemistry and Physiology, v.37, p.911-917, 1959. DOI: https://doi.org/10.1139/059-099

BRODERICK, A.; PATRICIO, A.. Chelonia mydas (South Atlantic subpopulation). In: The IUCN Red List of Threatened Species. 2019. DOI:

https://dx.doi.org/10.2305/IUCN.UK.20192.RLTS.T14212186 6A142086337.en

CARPENTIER, A. S.; BOOTH, D. T.; ARTHUR, K. E.; LIMPUS, C. J.. Stable isotope relationships between mothers, eggs and hatchlings in loggerhead sea turtles Caretta caretta. Marine Biology, v.162, p.783-797, 2015. DOI: https://doi.org/10.1007/s00227-015-2624-x

FRY, B.. Stable Isotope Ecology. New York: Springer-Verlag, 2008.

HATASE, H.; SATO, K.; YAMAGUCHI, M.; TAKAHASHI, K.; TSUKAMOTO, K.. Individual variation in feeding habitat use by adult female green sea turtles (Chelonia mydas): are they obligately neritic herbivores?. Oecologia, v.149, p.52-64, 2006. DOI: https://doi.org/10.1007/s00442-006-0431-2

HOBSON, K.. Tracing origins and migration of wildlife using stable isotopes: a review. Oecologia, v.120, p.314-326, 1999.

JACKSON, A. L.; INGER, R.; PARNELL, A. C.; BEARHOP, S.. Comparing isotopic niche widths among and within communities: SIBER - Stable Isotope Bayesian Ellipses in R. Journal of Animal Ecology, v.80, p.595-602, 2011. DOI: https://doi.org/10.1111/j.1365-2656.2011.01806.x

LAYMAN, C. A.; ARRINGTON, D. A.; MONTANA, C. G.; POST, D. M.. Can stable isotope ratios provide for community-wide measures of trophic structure?. Ecology, v.88, p.42-48, 2007. DOI: https://doi.org/10.1890/00129658(2007)88[42:csirpf]2.0.co;2

LOPÉZ-CASTRO, M. C.; BJORDNAL, K. A.; BOLTEN, A. B.. Evaluation of scute thickness to infer life history records in the carapace of green and loggerhead turtles. Endangered
Species Research, v.24, p.191-196, 2014.

MACARTHUR, R. H.. Geographical ecology: patterns in the distribution of species. Princeton: Princeton University Press, 1984.

NEWSOME, S. D.; RIO, C. M. D.; BEARHOP, S.; PHILLIP, D. L.. A niche for isotopic ecology. Frontiers in Ecology and Environment, v.5, p.429-436, 2007. DOI: http://doi.org/10.1890/060150.01

POST, D. M.; LAYMAN, C. A.; ARRINGTON, D. A.; TAKIMOTO, G.; QUATTROCHI, J.; MONTAÑA, C. G.. Getting to the fat of the matter: models, methods and assumptions for dealing with lipids in stable isotope analyses. Oecologia, v.152, p.179-189, 2007. DOI: http://dx.doi.org/10.1007/s00442$\underline{006-0630-x}$

R CORE TEAM. R: A language and environment for statistical computing. Version 3.6.3. Viena: R Foundation for Statistical Computing, 2020.

RIO, C. M. D.; SABAT, P.; ANDERSON-SPRECHER, R.; GONZALEZ, S. P.. Dietary and isotopic specialization: the isotopic niche of three Cinclodes ovenbirds. Oecologia, v.161, p.149-159, 2009. DOI: https://doi.org/10.1007/s00442-009-1357-2

ROSTAL, D. C.; OWENS, D. W.; GRUMBLES, J. S.; MACKENZIE, D. S.; AMOSS JUNIOR, M. S.. Seasonal reproductive cycle of the Kemp's ridley sea turtle (Lepidochelys kempi). General and Comparative Endocrinology, v.109, p.232-243, 1998. DOI: https://doi.org/10.1006/gcen.1997.7026

SHIMADA, T.; LIMPUS, C. J.; HAMANN, M.; BELL, I.; ESTEBAN, N.; GROOM, R.; HAYS, G. C.. Fidelity to foraging sites after long migrations. Journal of Animal Ecology, v.89, p.10081016, 2020. DOI: https://doi.org/10.1111/1365-2656.13157

THOMSON, J. A.; WHITMAN, E. R.; GARCIA-ROJAS, M. I.; BELLGROVE, A.; EKINS, M.; HAYS, G. C.; HEITHAUS, M. R.. Individual specialization in a migratory grazer reflects longterm diet selectivity on a foraging ground: implications for isotope-based tracking. Oecologia, v.188, p.429-439, 2018. DOI: https://doi.org/10.1007/s00442-018-4218-z

WALLACE, B. P.; SEMINOFF, J. A.; KILHAM, S. S.; SPOTILA, J. R.; DUTTON, P. H.. Leatherback turtles as oceanographic indicators: stable isotope analyses reveal a trophic dichotomy between ocean basins. Marine Biology, v.149, p.953-960, 2006. DOI: https://doi.org/10.1007/s00227-006$\underline{0247-y}$

ZANDEN, H. B. V.; ARTHUR, K. E.; BOLTEN, A. B.; POPP, B. N.; LAGUEUX, C. J.; HARRISON, E.; CAMPBELL, C. L.; BJORNDAL, K. A.. Trophic ecology of a green turtle breeding population. Marine Ecology Progress Series, v.476, p.237-249, 2013a. DOI: https://doi.org/10.3354/meps10185

ZANDEN, H. B. V.; BJORNDAL, K. A.; BOLTEN, A. B.. Temporal consistency and individual specialization in resource use by green turtles in successive life stages. Oecologia, v.173, p.767-777, 2013b. DOI: https://doi.org/10.1007/s00442$\underline{013-2655-2}$

A CBPC - Companhia Brasileira de Produção Científica (CNPJ: 11.221.422/0001-03) detém os direitos materiais desta publicação. Os direitos referem-se à publicação do trabalho em qualquer parte do mundo, incluindo os direitos às renovações, expansões e disseminações da contribuição, bem como outros direitos subsidiários. Todos os trabalhos publicados eletronicamente poderão posteriormente ser publicados em coletâneas impressas sob coordenação da Sustenere Publishing, da Companhia Brasileira de Produção Científica e seus parceiros autorizados. Os (as) autores (as) preservam os direitos autorais, mas não têm permissão para a publicação da contribuição em outro meio, impresso ou digital, em português ou em tradução. 